\title{
A construção social da ordem e da subversão nos discursos da (e sobre a) população em situação de rua de Belo Horizonte
}

\section{The social construction of order and subversion at discourses of (and about) population in a street situation from Belo Horizonte}

\author{
BRUNO EDUARDO FREITAS HONORATO* \\ LUIZ ALEX SILVA SARAIVA** \\ EVERTON RODRIGUES DA SILVA***
}

\section{RESUMO}

Tomando como pano de fundo a ideia da formação de um mercado mundial de cidades e sua implicação na produção de um espaço urbano contemporâneo redutor da diversidade, o presente artigo procura revelar a construção social das noções de ordem e subversão nos discursos da população em situação de rua de Belo Horizonte (MG) e dos atores implicados (sociedade domiciliada, entidades de auxílio, representantes da municipalidade, polícia e comerciantes), a partir do quadro teórico-metodológico da análise do discurso francesa. Realizou-se uma observação participante, enfatizando-se as práticas subversivas das pessoas em situação de rua como forma de problematizar a associação entre ordem e normalidade e a relação da sociedade com o que ela considera um descartável urbano. Entende-se, portanto, a subversão como uma práxis política necessária para impulsionar a transformação social na direção de uma convivência humana mais afeita à diversidade cultural.

Palavras-chave: população em situação de rua; ordem e subversão; cidade segregada; análise de discurso.

* Universidade Federal de Minas Gerais - UFMG / Doutorando. brunoefh@gmail.com .

** Universidade Federal de Minas Gerais - UFMG / Professor Adjunto. saraivalas@gmail.com .

*** Universidade Federal de Minas Gerais - UFMG / Doutorando. everton.rsilva@gmail.com . 


\section{Abstract}

Taking as background the idea of formation of a world market of cities and its implication at production of a contemporary urban space redactor from diversity, this paper seeks to reveal the social construction of order and subversion notions at discourses of population in a street situation from Belo Horizonte (MG, Brazil), and from implicated actors (domiciled society, care entities, city and commerce representants and police), from a theoretical and methodological background based on French discourse analysis. We've made a participant observation, emphasizing subversive practices of population in a street situation as a way to arguing the association between order and normality, and the relation of society with something that it considers an urban displaceable. We comprehend that subversion is a necessary political practice to increase social transformation towards a human ambience which embraces cultural diversity.

Keywords: population in a street situation; order and subversion; segregate city; discourse analysis.

\section{INTRODUÇÃo}

O processo de urbanização brasileiro, acelerado na segunda metade do século $X X$, trouxe às cidades uma diversidade de fenômenos sem precedentes, dentre eles o crescimento da desigualdade social e o desenvolvimento de fronteiras internas, temas estudados por antropólogos e sociólogos de várias épocas (VELHO, 2000). No Brasil, os estudos de alguns pesquisadores (VELHO, 2000; 2006; VENTURINI, 2009; SOUZA, 2009; LIMENA, 2001; MARTINS, 2011; SAWAYA, 2006) ressaltam a importância de se entender o contexto urbano como o locus da sociedade moderna e da sua dinâmica comportamental e investigá-lo não somente em suas dimensões materiais, mas também simbólicas (SARAIVA; CARRIERI, 2012), ideológicas (LEITE, 2007) e socioambientais (COSTA, 1997). Nessa leitura, a cidade torna-se um objeto de estudo de diversas áreas, possibilitando pesquisas interdisciplinares (SANTOS, 2007) e diversificadas que busquem compreendê-la em sua complexidade (LIMENA, 2001).

O presente trabalho apreende a urbe contemporânea a partir de uma abordagem do campo dos estudos urbanos que se apoia na 
noção de formação de um mercado mundial de cidades responsável por difundir no imaginário citadino um referencial de urbanização que tende a reduzir a pluralidade de práxis culturais coexistentes no território (JAYME; NEVES, 2010; LEFEBVRE, 1998; SANCHÉZ, 2001; SANTOS, 2000; SOUZA; BECHLER, 2008). A cidade-modelo que emerge das atuais diretrizes do planejamento público urbano dignifica o espaço como mercadoria de consumo, consolidando e criando novos limites socioespaciais (físicos e simbólicos) e, portanto, novas noções de ordem e subversão.

Diante dessa perspectiva, este estudo procura revelar a construção social do sentido de ordem e subversão presente nos discursos da população em situação de rua e dos atores implicados, tais como a sociedade domiciliada, as entidades de amparo organizadas em torno do trabalho voluntário e sem vinculação governamental, os representantes da municipalidade para a execução das políticas públicas de promoção e assistência social, a polícia e os comerciantes do entorno onde transita essa população. Em outros termos, a motivação da pesquisa está em conhecer as noções de ordem (normalidade) e subversão (desvio) acionadas pela sociedade, quando o assunto em questão diz respeito à população em situação de rua.

Os conceitos de ordem e subversão e as implicações políticas de se estudar a população em situação de rua foram pensados a partir do subsídio intelectual de Michel de Certeau (1925-1986). A noção de controle social conflita com os interesses do ser e constrange as ações mais ínfimas do seu dia a dia. Certeau lança-se na busca de uma abordagem que coloca em questão esse aspecto. O pensador francês, admirador de Michel Foucault, constrói seu pensamento centrado na captura das práticas cotidianas, isto é, dos momentos do dia a dia que revelam os aspectos sutis e profundos da dinâmica de interação entre o sujeito e o poder disseminado na estrutura social (JOSGRILBERG, 2005). Após a leitura de Vigiar e Punir, de Foucault, Certeau entende que, nas ações de controle social - representado pela imagem do panóptico de Jeremy Bentham consagrado por Foucault -, existem fissuras, às quais os sujeitos têm acesso, ainda que de maneira não consciente. Essas ações que exploram tais fissuras são chamadas, por Certeau (1998), de táticas: movimentos clandestinos que revelam momentos de transgressão 
do sujeito em relação às imposições do controle social. As táticas são, para o filósofo, a arte do fraco, o ato criador e insurgente por excelência diante das estratégias organizadas para a manutenção de uma hegemonia. Ordem e subversão, estratégia e tática no léxico de Certeau, são movimentos que não se separam e na sua oposição constante produzem-se mutuamente. Esse é um ponto-chave na analítica de Certeau. Mais do que tipificar os atos como ordeiros ou desviantes, cabe ao pesquisador descrever o jogo discursivo que engendra essa diferença - e constrói seu significado necessariamente social, pois é fruto das relações entre os homens - e suas implicações na configuração de posições na sociedade. Portanto, é pela via das microrrelações estabelecidas no cotidiano que Certeau compreende o poder e a política. Para ele, as lutas políticas são também lutas pela produção ${ }^{1}$ do espaço ordinário.

Nesse enquadramento, a subversão, entendida como a capacidade humana de ressignificar a realidade a partir de convicções outras que não as consideradas hegemônicas e normais (JOSGRILBERG, 2008), representa a possibilidade de criação de espaços de ação que permitam a renovação das práxis culturais. Resistir, ainda que de forma sutil, representa, para Certeau (1998), uma fração da história em que o fraco persiste e se impõe ao forte numa relação de poder. Portanto, compreender o significado da subversão no modo de vida da população em situação de rua permite conhecer com mais profundidade o sentido de ordem e os seus transbordamentos (como o preconceito) e como a sociedade lida com as pessoas e os fatos que ela não tolera. Permite compreender como o conceito de intolerância é construído (e se escora), evocando-se os ideais de legalidade definidos pelo Estado, quando essa via de pensamento, evidentemente, é conveniente para quem a aciona.

Desse modo, a escolha de Certeau não se deve apenas à caracterização peculiar que propõe das táticas e estratégias como momentos de poder, mas também pela relação da sua teoria com a capacidade

O termo "produção" é utilizado em seu sentido amplo, seguindo conceituação de Henri Lefebvre (1998). Para esse autor, os homens como seres sociais produzem sua vida, história, consciência, imaginação e seu mundo. Toda a realidade que se pode observar, toda a natureza que se pode imaginar é uma produção humana, isto é, efeito de uma permanente construção (simbolização) realizada pelo homem no cotidiano (no plano dos sujeitos em ação) de suas vidas. 
de insurgência dos anônimos sociais, dos fracos, daqueles que se encontram no silêncio e nas fissuras da estrutura dominante, como é o caso de muitos sujeitos ouvidos nesta pesquisa. Dar voz aos anônimos, àqueles considerados marginalizados, é um interesse de Certeau compartilhado por esta pesquisa.

O recorte espaço-temporal adotado foi a cidade de Belo Horizonte (MG), no período entre abril e junho de 2013, momentos nos quais a vida nela, especialmente o cotidiano dos marginalizados, estava expressivamente marcada pelas expectativas em relação às possíveis transformações socioespaciais em função da Copa das Confederações e da Copa do Mundo de 2014. Percebe-se nos discursos da população em situação de rua e de agentes do município uma incerteza em relação ao que poderia acontecer a essa população às vésperas dos dois grandes eventos. Essas incertezas tomam forma num município que possui um histórico de manejo humano ${ }^{2}$ em propostas de revitalização do seu centro urbano (CARRIERI; MARANHÃO; MURTA, 2009).

Este artigo está estruturado em seis tópicos. O primeiro aborda as diretrizes hegemônicas atuais do planejamento urbano e suas implicações na ordenação física e social do território. O segundo e o terceiro tópicos contextualizam a população em situação de rua nesse contexto citadino. $\mathrm{O}$ quarto item apresenta as diretrizes metodológicas do estudo, seguido pela análise dos discursos capturados, e por fim são elaboradas considerações finais.

\section{GESTÃO URBANA EM TEMPOS DE CITY MARKETING}

O termo city marketing ou marketing urbano é usado por Duarte e Czajkowski Junior (2007) e Leite (2010) para identificar uma nova fase em que vive o capitalismo no contexto urbano, revelando traços de como se dá o planejamento da cidade de acordo com interesses moldados pelo "olhar global" demandado por investidores multinacionais. As formas de uso do espaço inseridas na nova racionalidade do capitalismo são denunciadas por Sánchez (2001). A cidade assume feições de modelos preconcebidos representando as tendências

\footnotetext{
Termo usado por Carrieri, Maranhão e Murta (2009) para se referir às intervenções governamentais de manejo e transporte de grupos que estariam "prejudicando" a ideia de cidade almejada pelo governo.
} 
imaginadas pelos arquitetos e planejadores, buscando o que seriam as chamadas cidades-modelo. Os territórios são reorganizados com vistas a potencializar a eficiência econômica dos espaços por formas modernas de dominação e técnicas de manipulação cultural, a fim de que esses espaços sejam consumidos pela população local e mais ainda pela mídia mundial. Sánchez (2001, p. 31) afirma que as cidades-modelo "são imagens de marca construídas pela ação combinada de governos locais, junto a atores hegemônicos com interesses localizados, agências multilaterais e redes mundiais de cidades", nas quais espera-se florescer os resultados de uma boa gestão, empreendedora e moderna, dimensionada pela elevação de índices de desenvolvimento que se aproximam das cidades tidas como "modelos" mundialmente reconhecidos.

Nessa nova fase do capitalismo mundial, novas formas de divulgação são necessárias para vender a cidade. Formas que na gestão urbana se consolidam na produção/seleção de imagens que representam determinada visão de mundo sintetizada em um slogan ou numa afirmação sobre certa característica atribuída à urbe - a "cidade para todos" ou a "cidade maravilhosa" são exemplos nessa direção. As imagens-síntese das cidades, ou mesmo as cidades-síntese, são visões pautadas na valorização de dados aspectos discursivos que caminham diretamente para uma visão hegemônica da qualidade de vida dos cidadãos. Todavia, como colocam Souza e Bechler (2008), uma visão que foge à pluralidade e deixa de lado a diversidade de sentidos e pontos de vista, conferindo, assim, poder à unicidade, totalizando de forma reificada o que é múltiplo. A cidade, palco de diversas apropriações e reapropriações, passa a ser sintetizada sob o olhar interessado da ideologia neoliberal e começa a se organizar de maneira que as inadequações à sua "tendência global" sejam erradicadas. As leituras oficiais da cidade, empreendidas pela gestão pública, se propõem sempre objetivas e neutras, "apresentando fatos sociais como inquestionáveis" (SANCHÉZ, 2001, p. 34). Contudo, o realismo e a naturalidade dessas leituras são construídos por uma convenção social, em que se passa por natural aquilo que é um fato cultural.

O "normal" - ou as práticas de uma camada média da sociedade - é naturalizado nas mídias. A cidade é pensada para caber dentro de uma síntese normalizadora. Quando Canclini (2002) fala 
sobre a síntese imaginária da cidade, diz não apenas daquilo que é resumido para os olhos dos transeuntes em pequenas e confortáveis afirmações, mas também daquilo que não é contemplado: as margens da cidade, o excesso e a complexidade exagerada dos seus desvios. A prática de comunicar a cidade torna-se uma prática pensada pela gestão do urbano de maneira minuciosa com vistas a evitar qualquer discurso que explicite as contradições ocultas no cotidiano.

Além das estratégias midiáticas, a "cidade-modelo" é construída a partir de uma retórica persuasiva que configura uma agenda para a gestão municipal de modo que as pautas, ações e políticas empreendidas estejam alinhadas com uma visão hegemônica global e neoliberal do pensamento sobre a cidade, baseada numa representação específica encabeçada por uma parte seletiva da sociedade: aquela que tem potencial de investir e consumir os produtos que são localmente produzidos. Essa representação é avaliada por Santos (2000, p. 100) como parte discursiva de uma "inteligência global" que avalia, mede e classifica cada projeto de modernização urbana dentro de uma perspectiva de reinserção global.

O que dá substrato a esse projeto de cidade "modelo" é a orientação estratégica que encontra na gestão as ferramentas e instrumentos para sua concretização. Para Sánchez (2001), o processo de globalização em sua fase atual apresenta uma face do capitalismo em que as cidades são transformadas em mercadorias num processo de mercantilização do espaço. Produto do desenvolvimento do mundo da mercadoria, o fenômeno recente no qual se forma um mercado de cidades mostra a importância cada vez maior do espaço no capitalismo. A orientação para conquista do espaço é estratégica e visa, sobremaneira nesse momento, a alcançar as cidades como um todo, evidenciando a produção global de espaços sociais condicionados por um mercado mundial de cidades.

A legitimação da gestão é dada pela especialização do discurso, geralmente qualificado pelas narrativas de grandes arquitetos, experts em paisagismo e consultores de sucesso no meio empresarial, entre outros (SÁNCHEZ, 2001). Na leitura de Lefebvre (1998), a mercantilização das cidades vai além de apenas torná-las mercadorias, vendendo pequenas parcelas do espaço, pois procura realizar um projeto de reorganização da vida subordinada aos novos centros 
urbanos de decisão e estabelecer rumos para uma produção global e homogênea do espaço, no qual a diversidade manifesta reduz-se apenas às diferenças induzidas ou planejadas. $\mathrm{O}$ espaço abstrato, regido pela hegemonia do Estado e/ou capital privado, tenta impor sua lógica de uso e abafar a pluralidade de práxis culturais e espaciais que caracterizam a vida social.

A cidade planejada é aquela em que os engenheiros, arquitetos e gestores manipulam os recursos de construção a fim de estabelecerem o fluxo e os obstáculos à circulação nela. Certeau (1998) chama atenção para essa forma de conceber a urbe. A cidade-conceito de Certeau (1998) representa a manifestação mais utópica da cidade, delineada nos gabinetes dos arquitetos e urbanistas, de maneira a permitir generalizações diversas sobre a composição dos seus espaços e, sobretudo, na existência de um urbano com formas bem definidas. Essa noção estática de cidade é confrontada, pelo filósofo, com a proposta de uma cidade praticada. Esse deslocamento epistemológico proposto por Certeau - e empreendido por Mendes e Cavedon (2012) e Kunz, Heckert e Carvalho (2014) - abre espaço para o entendimento da cidade por meio das práticas urbanas. A cidade se faz conhecida pelo seu cotidiano, vivo nas ações dos seus cidadãos.

A análise da cidade como uma prática não exclui a importância dos elementos estruturais de concepção dela, mas, sobretudo, possibilita um espaço mais profundo para abordar o urbano em seu contexto microbiano, dentro dos muros e sob os tetos das casas e das construções públicas. O que determina o espaço é a prática que dele se faz (CERTEAU, 1998).

\section{A POPULAÇÃo EM SITUAÇÃo DE RUA COMO DESCARTÁVEL URBANO}

Albertsen e Diken (2001) introduzem o conceito de cidade como um lugar em que as pessoas se organizam por meio de regimes de justificativa (mundos que abrigam comportamentos e pensamentos comuns) e buscam conciliar seus interesses. Dentro dela, as pessoas se utilizam de diferentes regimes de justificativa para defender seus interesses e resolver as questões urbanas. Os regimes convivem na cidade e estabelecem diferentes relações entre o espaço e o indivíduo. No texto, os autores desenvolvem os regimes propostos por Boltanski e Thévenot (1991) (regimes de inspiração; opinião; 
domesticidade; civilidade; mercado; e indústria), e para eles as cidades foram inicialmente guiadas por um regime industrial, que elegeu a eficiência e a produtividade como grandezas essenciais à vida urbana.

Cada um desses regimes de justificativa detém uma noção de como as coisas devem funcionar. Por exemplo, no regime de justificativa industrial, que permeia a ordenação do espaço público, as grandezas valorizadas são a produtividade, a garantia de funcionalidade, eficiência, performance, além de respostas utilitárias às necessidades humanas. Cada uma dessas grandezas fortalece o argumento de que a sociedade deveria buscar funcionalidade, eficiência e precisão; isto é, a cidade passa a ser planejada e assegurada por um critério de eficiência e funcionalidade tanto quanto uma indústria. Dessa maneira, a ordem esperada em uma sociedade justificada por um regime industrial, assim como no paradigma epistemológico da cidade-modelo, seria aquela que descarta aquilo que se considera inútil ou ineficiente. Uma ordem que se fortalece pela funcionalidade (pelo utilitarismo) e abomina o ocioso.

A categoria das "populações vulneráveis" (ADORNO; VARANDA, 2004, p. 57) que, entre outras, engloba aquela em situação de rua, é considerada, nesse regime, uma população descartável e até prejudicial à ordem considerada "natural" da sociedade. Afinal, ela não garante eficiência alguma nos padrões pensados à maneira de uma "indústria-cidade" e também não interessa à vinculação imagética requerida de uma cidade-modelo globalmente amparada pelos investidores privados. A partir daí, as respostas dadas à existência dessas populações, consideradas ociosas, têm sido "medicalizantes", no sentido de "reduzir a dimensão de um problema social complexo a um diagnóstico médico clínico, ou entendê-la na dimensão dos preceitos higienistas e sanitaristas, na ótica da remoção das populações em circulação pelas cidades" (ADORNO; VARANDA, 2004, p. 57), ou proibitivas (NARDI; RIGONI, 2005), no sentido de não permitir manifestações que tenham visibilidade negativa diante desse regime, tal como no caso dos usuários de drogas (ilícitas, principalmente).

A noção de uma ordem que se justifica pela eficiência e pela utilidade de cada um para o interesse do todo implica o desenvolvimento do que Adorno e Varanda (2004) chamaram de população em 
situação de rua como descartáveis urbanos. Ora, se essa população não se insere na ordem funcional do regime das cidades, presume-se que ela pode ser indiferentemente descartada. Segundo Adorno e Varanda (2004, p. 67), “a concepção do descarte social aproxima as pessoas do lixo urbano e tal fenômeno pode estar relacionado com o aumento do número de pessoas que passaram a sobreviver com os materiais descartados pela cidade". O que seria "uma das dimensões mais perversas da sociedade globalizada: a relação nodal entre o descarte de produtos e materiais industrializados e o descarte de seres humanos" (ADORNO; VARANDA, 2004, p. 67). Nesse sentido, a ordem que preconiza a funcionalidade, e que também gera lixo, não deseja conviver com os produtos da própria existência, como também afirma Neves (2010). Enquanto o lixo gerado precisa ser removido, a população em situação de rua, que dele tira o seu sustento, torna-se, tanto quanto o próprio lixo que coleta, descartável diante dos domiciliados dessa mesma sociedade que lhe impôs a necessidade de ser útil.

\section{ORDEM E SUBVERSÃO: CONFLITOS DE LIBERDADE EM UMA SOCIEDADE FUNCIONAL}

Diante do exposto, interessa dizer que a ordem, como conceito, é entendida nesse trabalho como uma organização possível, planejada e executada segundo critérios de algum grupo social ou de um indivíduo, dentro de um regime definido que justifique, ou tente justificar, racionalmente, sua existência. A ordem, pensada como conceito, define um espaço e limita o "consumo" (CERTEAU, 1998, p. 16) que pode ser feito nesse espaço, estabelecendo regras de movimentação e possibilidades de ganho de cada parte envolvida.

A partir daí, sua contraparte, a subversão, relaciona-se às práticas de fuga dessa ordem. Como explicam Carrieri et al. (2008, p. 3), o termo subversão pode ser entendido como uma "reação de um conjunto de vozes marginalizadas e silenciadas pela estrutura dominante", tomando-se como fundamento que a subversão "opera na clandestinidade, e se sustenta através do conflito". Subverter é fazer uso ilegal, ou informal, daquilo que se espera que seja feito. Essa capacidade de agir em desconformidade com as imposições de determinado sistema organizado se funda nas reapropriações que 
os indivíduos fazem das normas e leis estabelecidas por meio de diferentes usos (CERTEAU, 1998) de algo que supostamente deveria ser recebido passivamente.

As diferentes "maneiras de praticar" (CERTEAU, 1998, p. 16) possibilitam ao indivíduo uma manobra pelas margens desse sistema pelo encontro de vias informais que autorizam uma subversão das normas que ele determina. A subversão torna-se, portanto, a manifestação concreta da insurgência humana, a possibilidade inventiva que caracteriza o homem. Subverter significa afirmar uma direção, uma perspectiva, um sentido, enfim demarcar uma via permanente de construção de uma práxis política alternativa e capaz de engendrar uma transformação social.

\section{PERCURSO Metodológico}

A opção epistemológica e metodológica realizada se alinha com a proposição de Fernando González Rey para uma pesquisa construtiva-interpretativa de natureza qualitativa. Para González Rey (2005), o ser humano não pode ser separado dos sentidos que produz em suas próprias ações; portanto, é um compromisso da pesquisa qualitativa investigar profundamente os sentidos que se expressam nas ações do sujeito, dando forma à categoria subjetividade. Em sua visão, estudar a subjetividade é lidar com um sistema complexo, e como tal ela não pode ser apreendida de forma imediata pelo observador. Desse modo, pesquisar fenômenos complexos inclui um envolvimento com o campo, uma atitude de se misturar ao campo de pesquisa. No léxico da epistemologia qualitativa proposta por González Rey (2005), esse princípio recebe o nome de caráter construtivo interpretativo do conhecimento sobre a realidade social, o que implica entender o processo de produção de saber científico não como uma apropriação linear da realidade que se apresenta ao pesquisador, mas como uma produção humana em constante construção e dependente de interpretação.

Por conseguinte, a compreensão dos sentidos das ações empreendidas pela população em situação de rua - que, por sua vez, fundamentam suas práticas cotidianas - foi um princípio estruturante da postura em campo. Guardando coerência com essa posição, a abordagem metodológica adotada é de inspiração etnográfica, 
conforme proposta por Angrosino (2009), fazendo uso do diário de campo $^{3}$, da observação participante e da entrevista semiestruturada.

A observação participante, diferente daquela comum do cotidiano, exige do pesquisador um foco sistemático e formal de observação, fazendo uso não apenas da visão, mas de todos os sentidos possíveis para captação de informações. Na pesquisa em questão, a técnica foi realizada por um dos autores do artigo e envolveu o acompanhamento, às sextas-feiras, durante três meses ${ }^{4}$ do ano de 2013, de uma equipe religiosa em sua atividade de auxílio (diálogos e distribuição de alimento) às pessoas em situação de rua em Belo Horizonte (MG). As narrativas e impressões vivenciadas nesse processo foram gravadas e registradas no diário de campo.

Havia certa dúvida se a inserção em campo por meio do grupo de auxílio inviabilizaria a realização de perguntas e observações fundamentais para a pesquisa, mas que, eventualmente, podiam divergir das normas do grupo. No entanto, desde março de 2012, mais de um ano antes do início do campo, um dos pesquisadores-autores já frequentava o grupo; esse fato propiciou relativa abertura para que ele tivesse, em paralelo com sua condição de membro do referido grupo, liberdade para investigar questões atinentes ao seu papel de pesquisador. Houve um primeiro momento de desconforto e desconfiança por parte da liderança do grupo, mas que desapareceu na medida em que a pesquisa não criou empecilhos para os trabalhos normais dos membros. $\mathrm{O}$ fato de o pesquisador já ser conhecido por todos os participantes ajudou-o a se inteirar das discussões existentes entre eles, aspecto que foi de grande valia para a composição do corpus discursivo da pesquisa.

As idas ao campo foram revelando particularidades do processo de construção do conhecimento a partir do espaço dialogal estabelecido pela observação participante. A primeira delas foi que algumas pessoas em situação de rua tinham um comportamento e

3 Trata-se de um instrumento de registro dos dados coletados no cotidiano da pesquisa. Esses registros podem ser descritivos e/ou reflexivos e devem trazer informações suficientes que permitam ao pesquisador, no momento da compreensão da realidade investigada, reconstruir as situações e os sentidos das ações observadas em campo (GEERTZ, 2008; ROESE et al., 2002).

4 A interrupção da pesquisa foi determinada quando se percebeu que os discursos estavam se repetindo e os acontecimentos deixaram de revelar um aspecto surpreendente. 
o discurso mais recatado diante dos grupos de auxílio, dificultando uma apreensão "efetiva" das práticas sociais. Há um mascaramento dos desejos/ações que cumpre um papel de socialização das pessoas de rua com os grupos que chegam até eles. Observou-se também o uso de mentiras e de histórias imaginárias nas conversas. Segundo Mendes (2007), esses tipos de relatos são justificáveis, uma vez que a vida na rua exige táticas diversas, como a mentira e a invenção, para sobreviver às dificuldades impostas. Também se observou que o caráter fortuito das narrativas decorre, com alguma frequência, do consumo habitual da bebida alcoólica e de drogas por parte dessa população - como também identificou Snow e Anderson (1998) -, o que, em algumas situações, torna o diálogo desconectado de um compromisso com a prática.

De forma geral, buscou-se lidar com a natureza relativa dos diálogos, adotando-se uma escuta mais apurada e seletiva e um método de aprofundamento nos assuntos, a fim de perceber eventuais contradições entre o que foi dito supostamente para agradar e aquilo que foi dito no desenrolar da conversa. A ideia de uma subversão contida no modo de se portar diante dos grupos de auxílio, seja para conseguir comida, seja para preservar-se diante dos observadores - quase sempre religiosos - configura também o que se pode chamar de táticas em relação ao observador. Essas táticas (cf. CERTEAU, 1998) já eram, de certa forma, previstas, embora o campo tenha sido definitivo para reafirmar essas expectativas.

É importante deixar claro que a dimensão ficcional dos discursos não os torna menos dignos de uma análise substancial de cunho científico, principalmente porque o relato, seja aquele que se diz fiel a uma realidade, seja o que assume a narrativa imaginária, é sempre subjetivo e intocado em sua construção íntima. Mesmo nas entrevistas semiestruturadas com os gestores se encontrarão desvios entre a ação e o discurso. A ficção, portanto, é uma característica aceita na opção epistemológica e metodológica feita nesta pesquisa.

A outra técnica utilizada foram as entrevistas semiestruturadas, um instrumento metodológico que, segundo Manzini (2004), parte de um roteiro com perguntas básicas, mas não se limita a elas, criando um espaço comunicativo mais aberto para as questões que emergem do contato pesquisador-pesquisado. As entrevistas foram realizadas 
logo após o período em que foi feita a observação participante, focalizando os diversos atores que participam da construção das políticas sociais para pessoas em situação de rua em Belo Horizonte. Foram entrevistados o gestor e a assistente social do albergue municipal ${ }^{5}$; técnicos da prefeitura; coordenadores e gestores dos equipamentos de amparo às pessoas em situação de rua, como o Centro de Referência em População de Rua (CRPR) de Belo Horizonte e a República Maria ${ }^{6}$; usuários do albergue; e a $\mathrm{ONG}^{7}$ Aliança de Misericórdia, vinculada à causa da população de rua. Esses diálogos foram gravados e posteriormente transcritos. Para fins didáticos, o Quadro 1 apresenta a codificação dos sujeitos ouvidos:

\section{Quadro 1: Codificação dos sujeitos entrevistados}

\begin{tabular}{|l|l|l|}
\hline Local das entrevistas & Sujeitos entrevistados & Código \\
\hline \multirow{2}{*}{ Albergue municipal } & Gestor geral & E1 \\
\cline { 2 - 3 } & $\begin{array}{l}\text { Coordenadora } \\
\text { de Assistência Social }\end{array}$ & E2 \\
\cline { 2 - 3 } & Pessoa em Situação de Rua 1 & PSR1 \\
\cline { 2 - 3 } Pessoa em Situação de Rua 2 & PSR2 \\
\hline $\begin{array}{l}\text { Secretaria de Políticas Sociais } \\
\text { de Belo Horizonte }\end{array}$ & $\begin{array}{l}\text { Assessora de Gabinete (Pre- } \\
\text { sidente do Comitê de Popu- } \\
\text { lação de Rua de Belo Hori- } \\
\text { zonte) }\end{array}$ & E3 \\
\hline ONG Aliança de Misericórdia & $\begin{array}{l}\text { Responsável pelo projeto em } \\
\text { Belo Horizonte }\end{array}$ & E4 \\
\hline Abordagem de rua & Técnico & E5 \\
\hline $\begin{array}{l}\text { Centro de Referência em Po- } \\
\text { pulação de Rua }\end{array}$ & Coordenador & E6 \\
\hline República Maria & Gestora geral & E7 \\
\hline
\end{tabular}

Fonte: Elaborado pelos autores.

5 O albergue é municipal e visa a atender à população em situação de rua, migrantes e trabalhadores desabrigados da Região Metropolitana de Belo Horizonte que precisam de pernoite.

6 A República Maria Maria é um órgão mantido pela prefeitura que abriga apenas mulheres em situação de rua, tem uma lotação bastante limitada, embora a permanência não seja interrompida durante o dia como no albergue.

7 A ONG Aliança de Misericórdia é uma das ONGs mais importantes da cidade no trabalho diretamente com a população em situação de rua em Belo Horizonte. 
Os relatos da população em situação de rua coletados durante a observação participante somaram-se às entrevistas mencionadas no Quadro 1, formando um corpus analítico da pesquisa. Esse corpus discursivo foi trabalhado mediante a proposta teórico-metodológica da análise do discurso francesa. Essa abordagem considera o discurso em sua constituição social expressa na estrutura gramatical, na semântica e na ideologia imanente ao texto. A análise do discurso (AD) se utiliza de elementos lexicais e de atribuições de sentido nas falas para interpretar o caminho empreendido pelo enunciador para construir um significado à sua enunciação. Trata-se de uma técnica que não se limita à análise linguística de um texto, implicando uma decifração de aspectos implícitos e explícitos na construção discursiva. Resumidamente, o roteiro empreendido para a AD foi baseado na identificação e análise:

- lexical $^{8}$;

- dos temas ${ }^{9}$ e figuras ${ }^{10}$ (explícitos ou implícitos) dos discursos, inclusive os personagens;

- dos percursos semânticos ${ }^{11}$ estruturados a partir dos temas e figuras;

- dos aspectos interdiscursivos ${ }^{12}$;

- dos aspectos da sintaxe discursiva ${ }^{13}$;

\footnotetext{
Análise do vocabulário usado em um enunciado discursivo.

Elementos mais abstratos de um discurso.

Elementos mais concretos de um discurso.

11 "[...] Corresponde à recorrência, ao longo do discurso, de elementos semânticos subjacentes" (FARIA, 1998, p. 142). "[...] A noção de percurso semântico engloba os conceitos greimasianos de percurso temático e percurso figurativo, correspondentes à recorrência de elementos semânticos mais abstratos ou mais concretos, respectivamente" (FARIA, 1998, p. 150).

12 De acordo com Mainguenau (1998, p. 86), “[...] pode-se chamar interdiscurso um conjunto de discursos. [...] Se consideramos um discurso particular, podemos também chamar interdiscurso o conjunto das unidades discursivas com as quais ele entra em relação". Fiorin $(1999$, p. 231) complementa que "[...] a identidade de um discurso depende de sua relação com outros, isto é, que ele não se constitui independentemente a outros discursos, para, em seguida, pôr-se em relação com eles, mas se constrói, de maneira regrada, no interior dessa oposição, definem-se nos limites dessa relação polêmica".

13 A sintaxe discursiva se refere à estrutura pela qual um discurso é construído, à forma como um enunciado discursivo é estruturado. Inclui figuras de linguagem, como metáforas, metonímias, prosopopeias e hipérboles.
} 
- dos aspectos refletidos e refratados ${ }^{14}$ nos discursos;

- das condições sociais de produção dos discursos ${ }^{15}$;

- dos discursos ${ }^{16}$ presentes no texto;

- dos aspectos ideológicos ${ }^{17}$ defendidos nesses discursos;

- dos aspectos ideológicos combatidos nesses discursos;

- da posição do texto em relação ao discurso hegemônico ${ }^{18}$ na sociedade em que se situa.

Esse roteiro foi sistematizado por Saraiva (2009) a partir de procedimentos propostos pelo professor Antonio Augusto Moreira de Faria, da Faculdade de Letras da Universidade Federal de Minas Gerais, para a análise do discurso na vertente francesa.

\section{OS disCURSOS dA (E SOBRE A) POPULAÇÃo EM SITUAÇÃo DE RUA}

A análise do corpus discursivo revelou as seguintes categorias analíticas, desenvolvidas nos subtópicos adiante ${ }^{19}$ : (i) sujeira na cidade: o controle pela limpeza dos corpos; (ii) subversão pelas construções indevidas no espaço público; (iii) a rua como prática

14 Refração linguística é uma estratégia discursiva analisada por Bakhtin (2006) que parte da ressignificação dos temas nos discursos. Todo aspecto é, ao mesmo tempo, refletido linguisticamente, preservando seu sentido socialmente estabelecido, e refratado, isto é, reinterpretado conforme os referenciais dos enunciadores. Um discurso, assim, reproduz (ou reflete) as condições sociais em que é produzido e modifica (ou refrata) determinados aspectos, de acordo com as ressignificações de seus enunciadores.

15 Além do contexto da enunciação discursiva, referem-se às condições reais de que o enunciador dispunha para que enunciasse o discurso daquela forma e não de outra qualquer. Em outras palavras, identifica-se aqui a partir de quais elementos sociais o discurso é produzido.

16 São entendidos como produção social de textos.

17 Em termos discursivos, ideologia se refere à intenção do texto socialmente produzido, isto é, a posição imanente a dado enunciado discursivo. Como não há discurso neutro, ele necessariamente apresenta uma posição que é defendida. Da mesma forma, já se posiciona sobre o que combate em termos ideológicos.

18 Neste item, se coteja a posição defendida no discurso com a hegemonia discursiva na sociedade, podendo ser identificado se o discurso se alinha ao que é dominante em termos sociais ou se constitui algo marginal.

19 Os recortes discursivos utilizados na análise foram identificados conforme o seguinte padrão: os fragmentos dizem respeito às falas das entrevistas; as narrativas são anotações no diário de campo dos relatos das pessoas ouvidas durante a observação participante; e o que está como registro do diário de campo são observações de um dos autores feitas no diário de campo durante a observação participante. Há casos em que os fragmentos e as narrativas são identificados por uma numeração não sequencial. Isso ocorre porque eles foram extraídos de um corpus mais amplo. 
de liberdade; (iv) embates entre as organizações institucionais de amparo e a sociedade civil; e (v) ir e vir sim, permanecer jamais.

\section{Sujeira na cidade: o controle pela limpeza dos corpos}

Os fragmentos na sequência são relatos de pessoas em situação de rua que se contrapõem à expectativa de normalidade que a vida em sociedade sugere e ao argumento de que o albergue é bom para todos. Revelam também aspectos da discriminação em relação à vida na rua.

(003) Pra população tem esse lado, em geral né?, e tem o lado também de... é... de um pessoal que ficaria na rua, não fica na rua porque fica num ambiente institucionalizado é bom pra todos né? Porque a pessoa ta mais dignamente sendo atendida e a rua fica menos em situação $\underline{\text { de degradação }}$ de preocupação de risco, das pessoas se sentirem intimidadas, chocadas. (E1)

(004) Eu moro no barro preto, eu deparo com situações daqueles passeiões que eles fizeram, que são ideias arquitetônicas pra encontro e que são usados como se fossem albergues descobertos né? E a dificuldade é enorme das lojas abrirem com um padrão de higiene e ao mesmo tempo isso não atrai fregueses, clientes, aí eles não dão conta do aluguel comercial que em Belo Horizonte está muito caro. Isso gera uma tensão, uma indignação, as partes né? É um conflito muito difícil, os dois lados tem suas razoes e ao mesmo tempo o conflito urbano é inegável. Já disseram que no Canadá, em Paris, nesses lugares todos também é assim né? (E5)

No fragmento (003), pela seleção lexical “a rua fica menos em situação de degradação, de preocupação de risco, das pessoas se sentirem intimidadas, chocadas", tem-se o implícito subentendido de que as pessoas em situação de rua degradam o ambiente da rua, oferecem riscos aos transeuntes, intimidam os passantes e os deixam chocados, tendo o albergue municipal como solução parcial para esse "problema" social "porque fica num ambiente institucional".

A situação de rua que enquadra essa população na categoria das "populações vulneráveis" (ADORNO; VARANDA, 2004, p. 57) é 
entendida como um "problema" social. Ora, se o regime de ordenamento da vida urbana trata a cidade como uma indústria geradora de eficiência e utilidade em todos os seus aspectos, a situação de rua torna-se um empecilho à noção de um espaço público funcional. Aquilo que não tem função torna-se inútil - os "descartáveis sociais" ou "descartáveis urbanos" (ADORNO; VARANDA, 2004, p. 67). Ficar no albergue em detrimento de ficar nas ruas é, antes de qualquer coisa, um argumento que reforça a manutenção da ordem em uma cidade eficiente. Quanto mais ordenável e controlável o espaço público, mais eficiente ele será.

A seleção lexical "isso é bom para todos" reflete o discurso de que as pessoas em situação de rua são incômodas para a sociedade. O interdiscurso se faz entre "isso é bom para todos" e o discurso da "cidade para todos", lema de uma gestão urbana que se intitula defensora de uma urbe mais digna, mais "limpa" e mais "confortável" aos olhos dos transeuntes. A limpeza e a ordem social são as escoras de uma cidade pronta para o consumo. Para Sánchez (2001, p. 38), “a discussão acerca dos processos de reestruturação urbana e da 'necessidade de inserção competitiva das cidades' vem acompanhada por uma significativa mudança na linguagem relativa ao planejamento e à gestão". Há, assim, uma incorporação do discurso da efetividade e da objetividade na gestão das metrópoles. Por conseguinte, as políticas de revitalização pressupõem a ressignificação dos espaços urbanos para atrair novos capitais e consumidores (JAYME; NEVES, 2010), inventando tradições e novas vocações para a cidade (FELDMAN-BIANCO, 2009). A cidade "limpa" que é boa para "todos" reflete a visão do city marketing, de uma cidade feita para ser consumida em todos os aspectos.

Nesse contexto, Canclini (2002) afirma que os meios de comunicação passam a inventar e reinventar a metrópole e seus cidadãos, tornando-se um dos principais construtores do imaginário urbano. $\mathrm{O}$ mesmo autor dirá que os discursos promovidos por esses agentes são propostos como "síntese imaginária do sentido da cidade". No caso da síntese da "cidade para todos" ficam excluídas as "populações vulneráveis" marginalizadas, o excesso tido como lixo urbano. A multiplicidade dos discursos que compõem a urbe é reduzida para 
caber dentro da normalidade. A cidade síntese é aquela em que se naturaliza o "normal" e se exclui o diferente.

Notemos ainda, no fragmento (004), que para validar a ideia de que uma cidade limpa é uma cidade com "progresso", o enunciador remete ao Canadá e a Paris, o primeiro mundo "limpo" e "desenvolvido", ao qual se procura seguir com a higienização da cidade. A hegemonia aqui se estabelece transpassando o pensamento local, baseando-se no que é feito em outros contextos como justificativa para certas ações. A legitimação das práticas de uma gestão urbana voltada para a comercialização da cidade envolve especialmente uma perspectiva de acompanhamento dos "modelos" de cidade global, como afirma Sánchez (2001). A forma como se veem o "progresso" e o desenvolvimento das cidades é associada à ideia de "boas práticas" de gestão, independentemente da conotação política e ideológica que elas possam refletir. Assim, a limpeza social e a higienização das ruas são assumidas como práticas de uma "boa" gestão, que promove, a despeito de qualquer empecilho, uma cidade que reflete os padrões de desenvolvimento mundiais do dito primeiro mundo.

Há uma refração linguística que fortalece esse argumento baseado na dignidade humana, conforme nota-se no léxico "a pessoa ta mais dignamente sendo atendida". A posição ideológica defendida pelo discurso é a de que as pessoas em situação de rua devem ir para o albergue e deixar as ruas livres para os cidadãos "normais". Ora, mas o que diferencia o cidadão "normal" de uma pessoa em situação de rua em uma "cidade para todos"?

O relato do dia 26 de abril de 2013, registrado no diário de campo, oferece um olhar contraditório ao discurso do fragmento (003) de que o albergue é "bom para todos".

Ângelo relatou ser um pedreiro conhecido de seu bairro que recentemente abandonou sua casa por ter sido traído pela mulher. Segundo ele a mulher morava, agora, com outro homem. Ângelo também disse ter uma filha de doze anos. Ângelo relatou que tentou dormir no albergue algumas vezes, mas que foi roubado. Segundo ele, lá os outros moradores de rua roubam suas vestes e seus cobertores, tendo ele que ficar atento. Por causa disso, Ângelo relatou não dormir bem durante dias. Ele relatou também que as pessoas que frequentam o albergue 
brigam lá dentro e que a vigilância não funciona bem. Segundo Ângelo, ele é cadastrado como morador de rua no Centro de Referência, mas não conseguiu jantar no restaurante popular naquele dia. No restaurante, alegaram que ele teria condições de arrumar o dinheiro para pagar a refeição. Ângelo agradeceu o lanche que havíamos lhe dado e o fato de termos o escutado. (Narrativa 03)

Outras narrativas também registram opiniões diversas do discurso dos membros do albergue em relação à convivência no local.

Perguntei a ele por que ele não dormia no albergue e ele me disse que tinha chegado há pouco mais de um mês na cidade e que tinha passado a primeira semana no albergue. Ele elogiou os agentes e a comida de lá, mas disse que lá era um lugar esquisito e que os moradores eram de difícil convivência. Disse que no albergue as pessoas urinavam nos quartos à noite e que defecavam nos lugares de tomar banho, deixando o ambiente anti-higiênico. Ele disse que isso não era pra ele. Disse ainda que lá, no albergue, havia muitos roubos durante a noite e que ele mesmo tinha sido roubado no primeiro dia. Marcos relatou que tinha vindo para Belo Horizonte porque não queria mais viver com seu irmão e sua avó em casa. Não aguentava mais a relação. Disse que estava procurando emprego, mas como tinha sido roubado, não tinha documentos suficientes, então teria que aguardar a assistência social para tirar os novos documentos. (Narrativa 04)

Um dos homens estava tremendo muito. A noite estava fria. Ele aceitou o lanche. Tremeu, e tremeu mais. Pensei que talvez ele estivesse simulando, mas na verdade eu também estava com frio nessa noite. Francisco retirou uma blusa da sua própria bolsa e deu ao homem que tremia. Ele agradeceu muito. Disse que era uma grande bênção e que estava muito satisfeito. Perguntei a ele por que ele não dormia no albergue e ele relatou que lá havia muita violência. Segundo ele, o albergue era um lugar de marginais. Ele já havia dormido lá uma vez, mas não gostara. Mas não me disse por quê. Como já estávamos atrasados não tive muito tempo para conversar. (Narrativa 05) 
Quando na narrativa (05) o homem se recusa a dormir no albergue, afirmando que lá é um lugar de marginais, podemos observar o potencial de resistência das pessoas em situação de rua, que não se resignam diante de qualquer opção que lhes seja oferecida como "teto"; isto é, elas preservam o senso de qualificar o lugar negativamente e de recusar-se a ir para lá. O aspecto da "degradação" é especialmente influente no comportamento da sociedade em relação a esse grupo social, pois o preconceito e a discriminação insurgem em vários momentos justificados pela associação comum entre moradores em situação de rua e o estado de sujeira e de falta de cuidado consigo próprio.

(005) Dessa situação de rua... não nasci na rua, ninguém te respeita, você sai andando na rua ai as pessoas fogem de você, escondem as bolsas, as mulheres escondem as bolsas, você é visto com maus olhos,

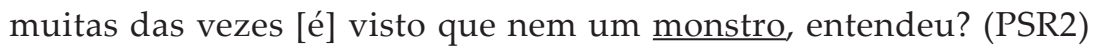

No fragmento (005, PSR2) vê-se o impacto do preconceito numa pessoa que "sofre" as suas consequências. O enunciador do fragmento, pessoa em situação de rua, relata o desrespeito, o medo e a hostilidade com que é tratado pela sociedade que pensa e age segundo uma ideia preconcebida de que o morador de rua é um "monstro", como explicita a figura de linguagem. A ideia de ter um albergue no qual se possa "estocar" essas pessoas e de que "isso é bom para todos" é concebida sobre os mesmos pressupostos que justificam a hostilidade da sociedade em relação à população em situação de rua e corrobora as ações de "manejo humano" (CARRIERI; MARANHÃO; MURTA, 2009). Rotular as pessoas em situação de rua como marginais é de alguma forma compreendê-las como uma exceção, algo que foge ao normal e que, por isso mesmo, constitui um desvio da ordem social naturalizada.

O que nos interessa problematizar é que o discurso da marginalidade e da exceção em nossa sociedade considerada "normal" é construído apropriando-se das manifestações socialmente codificadas como imorais, ilegais e anormais para designar aqueles que não conseguem, ou rejeitam, se adaptar aos preceitos dessa ordem. Logo, o "mal" é localizado na exceção. O discurso discriminatório 
tanto da sociedade em relação às pessoas em situação de rua quanto das próprias pessoas em situação de rua sobre si mesmas é materializado em falas como esta: "você é visto que nem um monstro, entendeu?". O preconceito e a discriminação vão além dessa fala, transformando-se em práticas de assassinato, estupros e agressões a essas pessoas, algo de certo modo aceitável pela sociedade normal. Ainda que esses atos de violência sejam cometidos por integrantes das classes sociais ditas de "elite", as justificativas são atribuídas a um merecimento da violência, da morte e do desprezo pela condição marginal e, portanto, anormal em que se encontram.

Outra forma possível de subversão à cidade foi registrada no diário de campo, como revelam os dois excertos abaixo:

Passando por um beco no qual a rua estava em construção, notei o odor fétido de urina e várias poças escorriam das paredes. O local era sujo e bastante escondido, parecia ser usado como "banheiro" pelos que não tinham outro lugar para suas necessidades.

Saí da Aliança e fui em direção aos viadutos, agora sozinho. Passando por lá, um homem chegou a vinte metros da minha frente, em lado de um viaduto e baixou as calças, defecando ali mesmo, sem se importar com a minha presença.

O caso do uso da cidade como depósito das necessidades fisiológicas dessas pessoas é fato comum para os estudos da área. A requisição de postos de banho e de banheiros públicos é antiga e não há nenhuma expectativa de que seja atendida. As táticas então se desenrolam pelo "consumo" indevido dos espaços públicos que se tornam banheiros ao ar livre, caracterizando outra forma de subversão às estratégias de manutenção da cidade limpa e "boa para todos".

\section{Subversão pelas construções indevidas no espaço público}

No fragmento (032) são exploradas as construções improvisadas feitas pela população em situação de rua. 
(032) isso é uma coisa interessante, as malocas são construções que passam por um campo afetivo, tem uns momentos que são "tretas" é um pegou a droga do outro, mas é interessante que às vezes tem núcleos, que às vezes a gente vai dormir na rua, sempre aquele grupinho e eles se constitui um núcleo afetivo mesmo ao ponto de construir amizades, tem uma maloca lá em São Paulo que é perto da Restaura-me e os caras é assim: "eu não tenho a grana hoje, eu fiz um corre mas não consegui, ele dá a droga, e aí em um outro momento ele dá a droga, e em outro momento eu consigo me reerguer vou trabalhar, eu vou lá e banco a cachaça para todo mundo", e é um tipo de relação que se estabelece de um ponto de vista afetivo... É como se isso atrai e é melhor que eu buscar voltar para a minha família, mesmo quando tendo a minha casa, mesmo tendo a minha cama, é melhor eu ta naquele tipo de realidade e naquele tipo de relacionamento que eu construí do que lá porque me exige menos, na rua quem que exige o que de quem? Nada, eu faço o que eu quero, eu durmo aonde eu quero, faço o que eu quero. (E4 falando em nome dos "moradores de rua")

O enunciador usa a figura da "maloca" para representar as construções improvisadas de "casa" das pessoas em situação de rua. Essas "casas" surgem como uma forma de associação, ou pequena organização, de grupos que se identificam e se dispõem a sustentar suas necessidades em conjunto. As seleções lexicais "sempre aquele grupinho" e "núcleo afetivo" são utilizadas para reforçar a ideia de construção afetiva e familiar no grupo.

É interessante notar que as "malocas", como estudado por Mendes (2007), constituem-se ilegalmente nas ruas, nas marquises e, principalmente, embaixo de viadutos. Configuram, portanto, uma forma de subversão. Um percurso semântico possível é o da "subversão em relação às leis municipais", que é uma forma de modificar os usos esperados da cidade. Se resgatarmos as contribuições de Sánchez (2001), percebemos que a cidade feita para ser consumida é livre de "malocas" que impeçam o trânsito dos pedestres, ou turistas, e livres das casas improvisadas que "sujam" a visão nos parques e nas praças. A cidade repleta de "malocas" não é aquela que a imprensa quer comunicar (cf. CANCLINI, 2002). Essa cidade, 
que é suja, deve estar longe da imagem da metrópole veiculada nas redes de comunicação locais e mundiais.

A prática da "maloca" consiste em operações táticas em relação às tentativas estratégicas legais de composição da ordem social. A cidade é permeada pelas construções improvisadas, como é permeada por pessoas diversas com interesses múltiplos. Essa metrópole vivida e praticada é um território que foge do ideal da gestão urbana pensada pela municipalidade por meio de seus planejadores e urbanistas. As táticas refletem imediatamente os "furos" dessa gestão em controlar a população em situação de rua. As fissuras ficam expostas, não apenas nos cantos e nos bairros mais afastados, mas também na região central de Belo Horizonte. Vários são os casos de remoção dessas estruturas, mas ainda sim continuam surgindo mais e mais malocas, como pode ser observado nos registros de diário de campo:

Do outro lado da rua, havia uma marquise onde mais de vinte pessoas se agrupavam para o descanso. Enquanto passávamos, muitos deles nos olhavam com raiva ou com desprezo. Alguns aceitaram o lanche. Mas, o uso da droga era contínuo. Casas de papelão e camas de pano tornavam-se o ambiente possível para uma noite de sono. Dobrando a esquina, um sujeito que dorme com sua mulher construiu um quadrado de caixas de papelão estruturado para bloquear as correntes de vento. Dentro da "casa" ele fumava um cigarro enquanto a mulher, deitada, falava com ele. Oferecemos o lanche e eles aceitaram. Seguindo pelo caminho, avistamos uma pessoa deitada entre um carrinho de supermercado e com a cabeça dentro de uma caixa de papelão. Era um senhor que aparentava 60 anos de idade ou mais. Ele acordou e pegou o pão com bom humor, saudou-nos e agradeceu. Mais à frente, encontramos um pessoal que sempre dorme entre dois carrinhos lotados de papelão e que armaram também uma barraca de acampamento.

As pessoas faziam casas e fogueiras em baixo da escada que subia para a passarela. O odor era de fezes e urina humanas, talvez. Muito lixo e fogo eram o destaque do cenário inicial da nossa noite missionária. Quando chegamos até Claudia, que não aceitava os pães, encontramonos, também, com um grupo de seis moradores de rua que ainda não 
tínhamos visto por ali. Eles estavam todos deitados em um cobertor grande. Um deles improvisava uma cozinha ao ar livre. Com alguns tijolos fazendo a base de um fogareiro, ele cozinhava algumas coisas, que não pude identificar bem o que eram, dentro de uma lata de tinta. $\mathrm{O}$ fogo estava forte e a água borbulhava dentro da lata fervendo.

As casas e camas de papelão são de uso frequente dessa população. Embaixo dos viadutos e nas rotas do hipercentro de Belo Horizonte essas construções temporárias são visíveis a qualquer momento da noite. Da mesma forma, as fogueiras e os cobertores estão espalhados pela cidade, a despeito do que desejaria boa parte da sociedade domiciliada.

Outro fato registrado no diário de campo se refere ao uso de uma televisão por um grupo de pessoas de rua que estava vivendo em uma praça.

Chegando a uma igreja, localizada no centro de uma praça, encontramos um grupo de mais ou menos dez pessoas deitados formando quase uma pequena comunidade de moradores de rua. Eles eram mais jovens, entre vinte e trinta anos e tinham cobertores e roupas espalhados pelo chão. Também haviam algumas mulheres. Um deles me pediu meu colar e eu recusei, dizendo que tinha ganhado e por isso não poderia dá-lo. Me chamou atenção o fato de que eles tinham uma televisão instalada e funcionando, ainda que de maneira bastante fraca, no meio da praça. Eles se gabavam de estar assistindo televisão ali e sorriam brincando ironicamente que estavam "chiques".

Muitas são as circunstâncias em que as normas da cidade perdem sentido diante das manifestações da população em situação de rua. Assistir televisão no meio de uma praça é algo pouco convencional e sinaliza as múltiplas formas possíveis de se apropriar subversivamente da metrópole contemporânea.

\section{A rua como prática de liberdade}

Nos fragmentos (038) e (039) a questão da responsabilização da população em situação de rua é abordada. A possibilidade de viver nas ruas como uma escolha também é discutida considerando as implicações que daí advêm. 
(038) Porque aonde tem um grupo de morador de rua tudo que acontece ali é atribuído a eles, sendo eles ou não os causadores. Então apesar de ser um público, ele é cidadão como qualquer outro cidadão, ele deve ser tratado da mesma forma como se trata qualquer outro cidadão, mas ele tem uma peculiaridade também ele é criado como um rebelde da sociedade é um rebelde que não esta se adaptando a esse sistema, o sistema é o que, as coisas estão tudo prontinho, tudo certinho a gente trabalha o dia inteiro a tarde vai para a casa, às vezes ele tem a casa e não que ir mesmo que tenha ou tendo a possibilidade de ter essa casa, ele quer gastar o dinheiro de outra forma, "eu quero beber" né! isso é estar em desconformidade com o sistema? É, né. (E5)

(039) Mesmo quando ele vem para rua, ele tem a casa, ou a partir do momento que lhe é ofertado uma casa, ele ainda assim insisti em permanecer na rua com maior ou menor grau de lucidez, ele tá escolhendo, não sei com que grau de lucidez, mas ele está escolhendo e mesmo porque não é às vezes uma pessoa com grau de sofrimento mental explicito, né, pode até ser embutido as vezes, latente, até, escolher viver nas ruas então feito essa escolha a gente não tem o que fazer a não ser assistir essa pessoa e não desistir, o ser humano...(E5)

No fragmento (038) o tema da "responsabilização" surge pela seleção lexical "tudo o que acontece ali é atribuído a eles sendo eles ou não os causadores", uma vez que a personagem "eles" refere-se às pessoas em situação de rua. $\mathrm{O}$ enunciador do fragmento defende que as pessoas de rua são cidadãos como quaisquer outros e que por isso têm direito de gastar seu dinheiro como bem entendem. Isso se confirma pela seleção lexical "às vezes ele tem a casa e não que ir mesmo que tenha ou tendo a possibilidade de ter essa casa, ele quer gastar o dinheiro de outra forma".

O percurso semântico da "escolha pela rua" surge pela primeira vez, identificando um caminho alternativo ao discurso da "insubmissão" como causa primordial da condição de rua. A figura do "sistema" aparece também como uma representação do discurso hegemônico ao qual a pessoa de rua não se adapta. O discurso do fragmento (038) é radicalmente contrário ao discurso hegemônico que pressupõe uma adaptação obrigatória como condição de garantia dos direitos de cidadão. 
Um aspecto importante sobre as condições materiais de produção do discurso do fragmento (038) é que o enunciador trabalha no serviço de abordagem de rua há mais de dez anos. Isso significa que o contato entre o enunciador e o grupo social em investigação é constante e direto, de forma que o que qualifica sua argumentação é justamente a possibilidade de ouvir e compreender os motivos pessoais (no que diz respeito à opção de estar nas ruas) dessas pessoas, na medida em que isso é parte essencial do trabalho dele. Nesse sentido, é interessante notar que se trata de um discurso que não "vitimiza" ou moraliza a abordagem, apenas constata que há um direito em jogo e que o papel da prefeitura é o de não desistir do cidadão em situação de rua. A opção pelas ruas ou o percurso da "escolha" é para o enunciador uma possibilidade, conforme revela outra passagem registrada no diário de campo do dia 10 de maio de 2013:

Passando por eles, encontramos Reinaldo, um amigo de João (líder do grupo), que relatou que estava tudo bem, porque tinha encontrado sua mãe no dia anterior. Segundo ele, tudo estava certo com ela e ele estava feliz por tê-la visto. Ele disse que iria encontrá-la no dia das mães e passaria o dia com ela para felicitá-la. Disse ainda que tinha comprado um presente pra ela. Reinaldo ainda disse que tinha uma casa e que, apesar disso, não queira ir pra lá. Disse ele: "a gente vicia na rua, não é? Não sei o que acontece". Reinaldo relatou que poderia morar em outro lugar se quisesse, mas que tinha "viciado" na rua... Pelo que eu entendi, Reinaldo não tinha problemas que o impusessem a vida na rua, mas estava ali por uma mistura de escolha com necessidade. Nosso diálogo não demorou. João depois me explicou que Reinaldo estava na rua há muito tempo, e que não tinha uma relação fixa com a moradia. Disse que ele ia para casa, mas que não aguentava ficar mais que uma semana e voltava sempre para a rua. João disse que, no começo, ele acompanhava outros dois moradores de rua que morreram depois de algum tempo, os dois de cirrose.

O discurso da "escolha pela rua" não é esvaziado das consequências que acarretam essa decisão, entretanto a análise precisa ser mediada pelo "lugar" político em que se encontra a população em 
situação de rua na atualidade, que é um "lugar" desprivilegiado pela sociedade e pela divisão social e econômica em geral.

(040) Se ele não maneirasse ele ia ficar, "você tem que maneirar aqui" ele deu uma abaixada, ele entende que ele sendo uma pessoa em situação de rua ele tem dificuldade de lidar com esses limites, mas o policial não vai entender né? Outros segmentos da sociedade não vai entender e se ele quebrar tudo ele tem que ser preso mesmo porque qualquer cidadão vai, se eu quebrar alguma coisa, eu também vou preso, tem que responder pelo seus atos, né? A gente não é paternalista também não, eu não vou mandar a polícia prender nenhum morador de rua, mas assim se ele ta roubando e ele for preso porque roubou, a gente nem entra muito nesses meandros ai. (E5)

No fragmento (040) há um percurso semântico dos "deveres da pessoa em situação de rua", vê-se pela seleção lexical "se ele quebrar tudo ele tem que ser preso mesmo porque qualquer cidadão vai". O enunciador iguala a população em situação de rua à população domiciliada, no que diz respeito aos direitos e deveres de um cidadão. A responsabilidade pelos atos é uma condição política de assunção da cidadania, embora se saiba que no momento atual essa população está em desvantagem do ponto de vista da força política que detém como grupo social. Esse discurso se opõe ao discurso do assistencialismo, ou como explicitado pelo enunciador, do "paternalismo", e também à visão de certos grupos da sociedade para os quais os moradores de rua são invisíveis e, portanto, direitos e deveres não seriam necessários.

\section{Embates entre as organizações institucionais de amparo e a sociedade civil}

Essa categoria de análise relaciona alguns dos problemas que permeiam a gestão das organizações institucionais que lidam com as pessoas em situação de rua e os grupos da sociedade civil que compõem o complexo quadro de auxílio e interação com essa população. O fragmento (041) aborda a inserção do albergue no tecido social cotidiano. 
(041) O Albergue ele tem uma autonomia e ele tem uma inserção na cidade. Essa inserção ela é tensa. Tem um grupo que precisa dele e também o grupo governamental que reconhece a identidade dele. Mas, tem um grupo de tensão que é o entorno né. A vizinhança, o pessoal que recrimina, às vezes, o pessoal em situação de rua e as instituições que trabalham com ele. Invés de considerar que é um trabalho especializado de atendimento, considera que é um grupo de incentivo e de geração de população de rua quando ele tá tentando fazer uma especialização e uma prevenção. Mas, a resposta também não é simples porque é um público também cheio de complexidades então. Então assim a parceria em termo de governamentais e tal já melhorou bastante. $\underline{O \text { desafio pra cidade hoje, que a cidade às vezes }}$ não se compenetra muito, não é o público que vem para o albergue, é o que não vem. É porque quando a gente conversa com alguém esclarece os nossos fundamentos, explica que se o pessoal não estivesse aqui estaria na rua e haveria mais 400 pessoas na rua. Ai isso impacta e o pessoal percebe melhor. Só que esse diálogo também muitas vezes não acontece, cada um fica com as suas ideias e o ideário normalmente ele é muito condenatório, ele é muito preconceituoso com esse público e com esse trabalho. Porque em termos governamentais o albergue busca algumas iniciativas e o albergue é uma delas. (E1)

No fragmento (041), o enunciador destaca o tema da "tensão" entre o albergue e a sociedade civil, em especial a "vizinhança", que se opõe, muitas vezes, à existência do albergue. $\mathrm{O}$ "entorno", como afirma o enunciador, "condena" e "recrimina" porque acredita que o albergue é um "gerador" de população de rua. O percurso semântico da "oposição da sociedade às organizações de amparo" possibilita uma leitura de como a sociedade civil, na figura da "vizinhança", reage à população de rua quando em proximidade a ela.

O principal aspecto defendido pelo discurso é o de que a população em situação de rua não é um problema para a sociedade, desde que esteja dentro do albergue - ou pelo menos frequentando-o. Isso se confirma pela seleção lexical "o desafio pra cidade hoje, que a cidade às vezes não se compenetra muito, não é o público que vem para o albergue, é o que não vem". A ideia de que as pessoas de rua deveriam estar em "casa" subentende que existe um modo 
"normal" ou "natural" em que a vida humana organizada ocorre; ou seja, em uma cidade "civilizada", as pessoas deveriam viver em "casa" e fazer suas necessidades em lugares privados. Ora, o albergue atende, em alguma dimensão, a essa expectativa da ordem social, mas não consegue restringir todos os comportamentos das pessoas em situação de rua. Especialmente nos momentos de transição, antes de entrar no albergue e logo após a saída, as pessoas de rua estão livres no "entorno" para agir da maneira que bem entender. Isso incomoda a população vizinha, porque perturba a noção de ordem e de privacidade incutida na sociedade domiciliada.

A forma como se compõe o discurso da "geração de população de rua" é bastante interessante porque reflete diretamente o preconceito em relação à existência dessas pessoas. A "vizinhança" supõe que esse grupo social é criado por causa do albergue, isto é, há uma ideia de incentivo à vida de rua. O preconceito da vizinhança é manifestado por meio da proposição de reuniões e debates para confrontar os interesses da prefeitura.

A situação que se afigura é a seguinte: a) as pessoas em situação de rua não devem ficar nas ruas, porque lá elas atrapalham o fluxo, impõem medo e sujam a cidade; b) o albergue, portanto, precisa existir, mas de forma alguma deve se localizar perto da "minha" casa. Logo, no limite, a solução que surge de um simulacro como esse seria: c) o albergue deve existir para "estocar" as pessoas de rua, bem longe da cidade e das pessoas "normais". Essa situação não é muito diferente da que expõe Marx (2011, p. 147) quando narra as decisões de Napoleão Bonaparte para acabar com a mendicância. A ideia à época, tal como se supõe acima, foi a de criar depósitos "que se transformavam em penitenciárias com tanta rapidez que bem depressa o pobre chegava aí exclusivamente pela estrada do tribunal da polícia correcional", de preferência isolados da população domiciliada.

Da mesma forma, quando se considera no fragmento (041) que o "desafio" para a "cidade" hoje não é o público que frequenta o albergue, mas aquele que não o frequenta, a lógica continua sendo a de que os frequentadores do albergue são menos "problemáticos" - porque não impõem o grande desafio - do que os não frequentadores. Combate-se no discurso do fragmento (041) a possibilidade 
de viver na rua, ou seja, apesar de criticar a posição da sociedade sobre o preconceito que ainda existe, subentende-se que o enunciador deixa claro que "bom seria se eles estivessem em casa". Nesse sentido o discurso do fragmento (041) se alinha ao que se valoriza socialmente, que é uma vida em casa, de preferência que não incomode o vizinho.

Ir e vir sim: permanecer, jamais

Nos fragmentos (046), (047), (048), (049) e (050) são discutidos os argumentos que tentam justificar uma posição de retirada compulsória das pessoas em situação de rua de suas casas improvisadas. Os recortes auxiliam a entender o quadro em que o discurso da internação compulsória se compõe na cidade.

(046) Nós não fazemos retirada compulsória, nós não fazemos internação compulsória, agora é bom que se deixe claro... o município, ele entende, e garante e reconhece o direito das pessoas de estarem na ruas é o direito de ir e vir previsto na nossa Constituição Federal. Contudo, o município não reconhece o direito das pessoas se estabelecerem nas ruas... (E3)

(047) Mas nós não vamos fazer nenhuma política de recolhimento dessas pessoas, não é essa a lógica com qual nós trabalhamos, a população de rua ta aí, nós não vamos tampar o sol com a peneira nem fazer de conta que ela não existe, o turista que vier vai se deparar com essa questão naturalmente, né, e o que nós vamos fazer, é o que eu te disse, tem um centro que passa a funcionar imediatamente para que essas pessoas tenham um lugar para ir também durante o dia né, a ideia é que a gente planeja é atividades da copa das confederações e da copa do mundo também nesses lugares, mas não vamos fazer internação compulsória e nem recolhimento compulsório. Havia um boato aí entre os moradores de rua que a gente ia passar um caminhão, ônibus, para recolher todo mundo, para levar para onde? Não tem lugar para levar... Então não vamos fazer isso. (E3)

No fragmento (046) surge o tema da "internação compulsória". O enunciador, membro da Secretaria de Políticas Sociais da prefeitu- 
ra, afirma que "eles" (entenda-se a prefeitura) não fazem internação compulsória. A seleção lexical que confirma essa afirmação é "nós não fazemos retirada compulsória". O principal aspecto defendido pelo discurso é o da abordagem legal da prefeitura, que invoca a figura da "Constituição Federal" para dar força ao argumento de que a municipalidade segue as regras impostas pela legislação federal.

O principal aspecto combatido pelo discurso é o de que as pessoas têm direito de viver nas ruas, uma vez que a Constituição garante o direito de ir e vir, mas não o de permanecer nas ruas. Um percurso semântico possível é o da "legalidade da vida nas ruas". Embora o enunciador assegure que a prefeitura não faz retirada compulsória, as narrativas das pessoas em situação de rua se opõem a essa afirmação. Esse "manejo humano" (cf. CARRIERI; MARANHÃO; MURTA, 2009) ocorre em vários momentos na cidade de Belo Horizonte, como se vê no relato de um dos membros do grupo de auxílio (chamado de Estevão) que acompanhamos durante o tempo de pesquisa:

A rota era longa e íamos com pressa. Perguntei para Estevão sobre os acontecimentos relativos à população em situação de rua na copa das confederações [que estava prestes a acontecer]. Estevão relatou que a prefeitura tiraria a população de rua das ruas no momento da copa e que isso aconteceria nos lugares de maior movimentação de turistas. Enquanto passávamos pela praça, ele também relatou que as crianças, que somavam cerca de trinta meninos de rua que ficavam por ali, também foram retiradas. Mas, segundo ele, o fato das crianças serem retiradas da praça aconteceu porque elas estavam atrapalhando muito os comércios do entorno, fazendo pequenos furtos nos estabelecimentos e roubando pessoas que passavam por ali. Então, a prefeitura e a polícia julgaram melhor tirar eles dali. Perguntei para onde eles tinham sido levados, mas nem Estevão, nem qualquer outro dos participantes do grupo, soube responder minha pergunta. Disseram apenas que não sabiam e que não dava pra saber. (Registro do diário de campo)

O tema é controverso para os próprios moradores de rua que dependem de informações e boatos que emergem por toda a parte. 
(048) Minha assistente social me avisou uma coisa e é fato, todos que estão aqui o que eles falam para mim é irrelevante, eu converso com quem mexe com os donos do boi então tem a verdadeira informação, por enquanto a [...] não conversou nada comigo sobre isso não, é uns dizem que vai ter um galpão lá para não sei aonde e que vão colocar todos lá dentro, não vai conseguir são 5.000 moradores de calçada o que você vai fazer com 5.000 moradores de calçada é complicado eu só escutei falar isso só. (PSR1)

No fragmento (048) há um implícito subentendido de que o que os usuários do albergue dizem sobre a "internação compulsória" é menos confiável do que o que diz a "assistente social". Há uma clara hierarquização social, em que as pessoas em situação de rua são colocadas como inferiores àquelas que ocupam, nesse caso, algum cargo dentro do albergue. A figura de um galpão é usada para representar a preocupação do enunciador com uma possível estratégia da prefeitura para internar as pessoas de rua. O principal aspecto defendido pelo discurso é o de que as pessoas em situação de rua não têm condições para dar uma informação de confiança, uma vez que a própria lógica - representada na fala "não vai conseguir são 5.000 moradores" - não permite que as inquietações/ suspeitas deles se verifiquem.

Interessante notar que as condições materiais de produção do discurso se referem a um usuário do albergue que dispõe de certa intimidade com a assistente social, que ele se referencia como "minha" e atribui uma confiança ("me avisou") e representa o que ele chama de "os donos do boi", ou seja, as pessoas de valor, ou com posse de recursos, o que não é o caso daquelas em situação de rua. O discurso no fragmento reforça a posição hegemônica de que os moradores de rua não são confiáveis, nem mesmo para uma informação.

Mendes (2007) relata alguns problemas relacionados à prática da mentira entre as pessoas de rua. Segundo a autora, tais indivíduos desenvolvem, pela própria condição de vida, estratégias para lidar com o discurso de maneira que a mentira se torna um recurso de persuasão para conseguir aquilo que se almeja, fato também mencionado por Snow e Anderson (1998). Esse aspecto, em algum nível, tende a criar um estigma sobre essa população, identificando-a com 
a mentira e levando a generalizações do tipo "morador de rua não fala a verdade". Nesse sentido, a autoridade de quem fala é associada à sua posição social, ou às suas posses, fortalecendo a hipótese de que em uma sociedade que se constitui por meio de critérios de eficiência, as pessoas que não têm posses ou uma posição reconhecida socialmente tendem a ser categorizadas como "descartáveis sociais" (ADORNO; VARANDA, 2004, p. 67).

(049) [O] proprietário, às vezes, é até solidário com essa pessoa oferece um café, um lanche, mas quer vê-lo longe dele e aí liga para a gente solicitando a abordagem pedindo para a gente tirar essa pessoa dali, via de regra é isso, higienização, nas regionais mais distantes, tem também, mas não é tanto as mais distantes do centro e a gente inverte essa lógica, as vezes a gente tem que ser educador para eles também, a gente não vai fazer a retirada, a gente não trabalha com retirada, a gente vai ai mas a ida nossa não significa a saída deles imediata né... "ah mas eu pago imposto!" você paga imposto ele também paga ele bebe água, só de beber água você ta pagando imposto... (E5)

No fragmento (049) vê-se que a posição sobre a "higienização" se reflete no discurso da sociedade que é assistencialista, "mas" quer a limpeza da rua, a boa estética e a não perturbação. Essa sociedade que alimenta e "doa" parte dos recursos necessários para a sobrevivência da população de rua também não quer se deparar com ela. A seleção lexical "e aí liga para a gente solicitando a abordagem pedindo para a gente tirar essa pessoa dali" confirma essa atitude. Um percurso semântico possível para leitura desse fragmento é o da "caridade contraditória", que em certa medida foi observada por Costa (2005). Essa prática sugere que na sociedade brasileira há, por um lado, o desinteresse e o preconceito, que por vezes se tornam atos de repressão social e higienização; por outro lado, há compaixão, preocupação e até o assistencialismo herdados de uma cultura religiosa, especialmente católica. Esses sentimentos estão refletidos no Estado brasileiro (COSTA, 2005), que ora se distancia da população de rua, ora se volta para ela com políticas e tentativas de amparo.

Uma implicação significativa do discurso caritativo e assistencialista é que há um esvaziamento da perspectiva política na qual as 
pessoas em situação de rua se encontram. Como se supõe que essa população é carente de recursos e precisa ser conduzida e auxiliada - via atitudes caridosas daqueles que têm condições para isso -, justifica-se também que ela pode ser constrangida/punida por uma força exterior. Tanto suas responsabilidades quanto seus direitos são outorgados a outrem sob a justificativa de uma "inconsciência" que inebria aquele que opta por morar nas ruas.

No caso brasileiro, o Estado historicamente assume essa posição de "pai repressor" em muitos momentos, característica que não foge aos preceitos da sociedade como um todo. Assim, não importando o "direito" e o "dever" desse cidadão, os quais são desconsiderados, mas a condição dele de "inconsciente" diante da economia capitalista, sugere-se que ele precisa ser compensado por uma atitude "paternalista". O Estado age segundo uma visão hegemônica de que as pessoas em situação de rua são incapazes de tomar atitudes "racionais"; logo, sendo "incapazes" não poderiam exigir seus direitos constitucionais. Assim, a sociedade e o Estado sentem-se à vontade para justificar a retirada e a realocação dessas pessoas, especialmente quando elas deixam de ser "agradáveis" à paisagem citadina. Sobre esse aspecto, o registro do diário de campo do dia 07 de junho de 2013 traz um exemplo:

Quando passamos por uma praça em que se localizava uma igreja, perguntei se não íamos até lá. Adelaide disse que não, e relatou que alguns dias antes o grupo teve um desentendimento com a polícia naquele lugar. Como eu já tinha ouvido falar antes, no fórum, um grupo de meninos de rua ficava ali naquela área cheirando tiner e executando pequenos furtos na região. Os moradores estavam irritados com a situação e chamaram a polícia. Segundo Adelaide, a polícia interveio no trabalho do grupo, no determinado dia, e disse diretamente a ela que se ela continuasse fazendo aquele trabalho, ela estaria contribuindo com o crime daqueles meninos. Ela ainda relatou que, no momento da conversa, o gerente de uma drogaria próxima e uma mulher dona de um pequeno hotel da região também aproveitaram para se aproximar e externar sua indignação quanto ao trabalho do grupo. Eles diziam que os meninos roubavam e que não deveriam ser alimentados daquela maneira, "de graça". Os guardas foram incisivos. 
Adelaide então disse que, a partir daquele dia, ela tinha parado de ir até a praça, ainda que indignada com o discurso do policial.

Ainda que haja posições contrárias à retirada compulsória dessas pessoas, como no discurso do fragmento (049) produzido por um técnico da abordagem de rua da prefeitura, vê-se que as narrativas empreendidas pelos atores ligados à esfera pública não são coesas e representam opiniões diversas.

(050) Pois é eu acredito que não vai ser feito essa higienização, eu to acreditando que a prefeitura vai investir mais em serviços, vai ter mais centros de referências eu to acreditando nisso eu credito que sim, pode ter ações higienistas pode porque a política ela é feita de várias faces, eu sei que dentro da política tem gente que quer essas ações higienistas, já foi até defendida inclusive, mas eu tenho acreditado que a prefeitura vai investir em outros projetos, então vamos tirar proveito disso também é... eu sei que está muito aquém a prefeitura de Belo Horizonte está muito aquém do que deveria ser para a população de rua, igual o que eu te falei tem coisas boas mas precisa fazer mais. (E6)

No fragmento (050), o enunciador deixa clara sua posição insegura sobre os acontecimentos referentes à possibilidade de limpeza social no período da Copa das Confederações de 2013 e da Copa do Mundo de 2014. Na seleção lexical "eu acredito", há um implícito subentendido de que a possibilidade de higienização é factível. A política que a prefeitura, especialmente a Secretaria de Políticas Sociais, intenta defender é a de não retirada da população de rua, que ali reside e se movimenta. Entretanto, os discursos dos atores que representam a prefeitura não parecem convergir.

No fragmento (050) o coordenador do Centro de Referência da População em Situação de Rua parece não saber o que será feito na época do evento, sinalizando uma falta de sintonia com o planejamento político que é expresso pela Secretaria de Políticas Sociais nos fragmentos (046) e (047). Também o gestor do albergue, quando questionado sobre o planejamento das ações da prefeitura para o evento, não soube falar, demonstrando falta de conhecimento acerca do assunto. Daí entende-se que os discursos dos atores e gestores que 
trabalham na prefeitura não são coesos, sugerindo certa vulnerabilidade aos argumentos apresentados nos fragmentos (046) e (047).

Em um dos registros no diário de campo do dia 31 de maio de 2013, há outro relato que faz referência às ações de higienização da prefeitura de Belo Horizonte:

Elizabeth, a líder do subgrupo em que participei, comentava sobre a semana anterior nessa mesma rota. Disse que, na sexta-feira anterior, muitas pessoas não estavam em seus locais de costume. Alguns dos moradores remanescentes justificaram que a prefeitura os tinha tirado de lá. Elizabeth também comentou que a prefeitura às vezes passava recolhendo casas de papelão, cobertores e colchões durante o período do frio, para que os moradores de rua procurassem outros lugares, ou mesmo cidades, para passarem a noite.

As práticas de limpeza social não se baseiam exclusivamente na remoção das pessoas de seus lugares de dormir, mas também em estratégias de coerção pela imposição de alguns constrangimentos, tais como o recolhimento das casas de papelão, dos cobertores e dos colchões durante o período de frio. Se a prefeitura insiste no discurso da não retirada compulsória, as narrativas registradas se opõem ao argumento de que não há intervenção pública.

A forma como a gestão urbana de Belo Horizonte lida com esses casos sugere uma aproximação com as práticas higienistas destacadas nos processos de gentrificação explorados por Leite (2008) e Botelho (2005). Embora não se possa dizer de uma prática de revitalização generalizada na cidade, a base da política de "manejo humano" (cf. CARRIERI; MARANHÃO; MURTA, 2009) continua sendo a mesma, ou seja, aquela em que se pressupõe que o "inconveniente" deve dar espaço àquilo que é valorizado pela gestão da cidade. Quer isso represente a retirada de camelôs do centro do município ou de pessoas em situação de rua dos espaços urbanos, essa prática ainda é baseada em uma hierarquia de posições sociais em que a autoridade reside essencialmente na capacidade de se fazer ouvir politicamente. 


\section{CONSIDERAÇõES FINAIS}

Olivier Voirol (2008) entende que a pesquisa sociológica deve se interessar pela esfera pública como um lugar de confrontação de enunciados, convicções morais e políticas defendidas pelos indivíduos ou grupos sociais. Essa confrontação é a base dos modos gregários de vida. Defende o autor que o compromisso da pesquisa é dar conta das diferenciações e dos conflitos entre os grupos sociais, dos modos de invisibilidade social e orientações morais informais que emergem na sociedade, enfatizando as condições simbólicas que definem a participação dos sujeitos na esfera pública.

Acreditamos que a pesquisa apresentada neste artigo ocupa o lugar mencionado por Voirol e sua principal contribuição está em enriquecer o conhecimento sobre as mediações inerentes à vida gregária. Buscamos seguir os moradores em situação de rua, descrever seus movimentos e relações que constituem suas práticas cotidianas e, desse modo, enfatizar a cidade invisível que excede os limites da racionalidade imposta pelo city marketing. $\mathrm{O}$ interesse por esse grupo social surge inspirado no convite de Michel de Certeau (1998) sobre a necessidade de as pesquisas sociais narrarem a arte dos fracos e anônimos. Henri Lefebvre (1998) e Viviane Mosé (2012) lembram-nos de que o nascimento da filosofia ocidental coincide com a exigência de ordem que a pólis grega requisitava. A cidade reclama a filosofia, que nasce significando lei e uma moral necessária para o domínio da intempestividade humana que ameaçava a virtualidade do urbano. Contra esse significado primeiro da filosofia, vários pensadores se rebelaram, reivindicando que a cidade seja apreendida como o locus da multiplicidade de práxis forjadas por sujeitos sociais atuantes em diferentes escalas. Certeau, assim como Lefebvre e tantos outros, são exemplos de ativistas-intelectuais que propuseram esse deslocamento, abrindo espaço para se enxergar o urbano por meio das microterritorialidades que emergem nas fissuras da ordem hegemônica.

A análise dos discursos dos moradores em situação de rua e dos agentes implicados - inspirada na vertente francesa, pautada na articulação entre as narrativas e suas instâncias de produção e enunciação - aponta para: (i) um uso subversivo dos espaços públicos da cidade (construção de malocas, espaço como depósito de necessida- 
des fisiológicas, ocupação de praças de modo não convencional etc.); (ii) um questionamento do enunciado-síntese de Belo Horizonte: uma "cidade para todos"; (iii) a existência de padrões de sociabilidade e acordos tácitos que regem a relação entre os moradores e os demais agentes sociais (domiciliados, comerciantes, polícia etc.), ainda que esses acordos variem e sejam suspensos em algumas situações; (iv) a insatisfação que o albergue provoca em alguns moradores e em sua vizinhança, essa última enxerga essa instituição como um dispositivo de estímulo à vida nas ruas; (v) a construção da noção de normalidade (isto é, de um indivíduo incluído socialmente) alicerçada no domínio de competências e no cumprimento de funções que ofereçam uma contribuição útil para a sociedade organizada em torno do trabalho capitalista e da cidade eficiente; (vi) a prática da "caridade contraditória", caracterizada por um comportamento social vacilante: ora vigora o desinteresse e o preconceito que legitima as ações de repressão social e higienização, ora a compaixão e o assistencialismo; e (vii) o reconhecimento político da "escolha pela rua" e pelo questionamento de uma adaptação obrigatória à ordem funcional da sociedade como um pressuposto para o usufruto de direitos civis e para obtenção de um respeito social.

A observação de tais práticas suscita o debate de vários temas complexos, que não são objeto do presente artigo, constituindo-se em possibilidades para pesquisas futuras. No entanto, para finalizar, julgamos que dois desses temas merecem breves comentários, a saber: o sentido atribuído à noção de transgressão e a vida na rua como uma escolha política ${ }^{20}$.

Quanto ao primeiro tema, limite e transgressão, inspirados por Mosé (2012), compreendemos que os homens precisam de limite para se organizar, isto é, de cultura (como sinônimo de civilização e de normalidade, não no seu sentido antropológico mais contemporâneo); ao mesmo tempo, necessitam suspender esses limites aproximando-se de sua natureza primária, a fim de refletir sobre si e despertar sua potência criativa. Morar na rua é uma experimentação dessa ausência de limites (essa experimentação varia em intensidade e duração). A pesquisa mostrou que essa vivência não

20 Tais temas foram escolhidos, pois perpassam toda a discussão desenvolvida no artigo. 
suspende completamente os limites sociais, na medida em que os moradores possuem uma lógica própria - e heterogênea entre o grupo - de se organizar, e na medida em que a transgressão surge na relação com a sociedade.

Viver em situação de rua é uma via de retorno a um modo de manejar o mundo mais fracamente mediado pela cultura ocidental que produz um ideal de normalidade. Não estamos sugerindo que os limites sejam desnecessários, sem eles não haveria pensamento, linguagem, sociedade etc. A ideia que assumimos é que o homem (no sentido mais geral de espécie humana) constrói-se permanentemente por meio da relação limite-transgressão. É o jogo entre esse par que formula o conceito de humanidade. A transgressão traz para o primeiro plano a heurística e as justificativas que levaram ao estabelecimento de limites. Esse é o seu potencial transformador ou não, pois na medida em que acentua os limites ela também tem a possibilidade de fortalecê-los, se nada for feito para mudá-los. $\mathrm{Na}$ transgressão o homem coloca em questão o seu ser - é nesse sentido que, para Mosé (2012), a transgressão é uma potência orgânica da vida, o desafio é dirigi-la e potencializá-la, simultaneamente.

Esse é um aprendizado relevante que extraímos do contato com os moradores em situação de rua. Ao conhecer suas práticas ficamos subitamente tocados pela necessidade de lutar para modificar características desse modo de viver (referimo-nos às condições sanitárias, de saúde, de invisibilidade e de violência física) e atuar na direção de retirá-los da rua. Somos alimentados pelo impulso de compreender a vida nas ruas como o signo da decrepitude humana. Mas, ao mesmo tempo, perguntamo-nos: é possível outra leitura? Acreditamos que sim. A experiência de contato com os moradores também nos provocou um novo olhar: a cultura humana fundada na razão (o nascimento da civilização reduziu o homem a pensar) é capaz de produzir um ideal de normalidade/verdade que é excludente. A cultura deu-nos a liberdade de pensar, mas, paradoxalmente, criou uma nova natureza, que também nos tiraniza (Mosé, 2012). A cultura da normalidade é, pois, essa estranha liberdade que a população em situação de rua não quer para si.

O segundo tema, que se refere a morar na rua, implica considerar esse aspecto também como uma escolha política que deve ir 
além. Quando a população em situação de rua é colocada no lugar de vítima ou de descartável urbano, ou ainda, de incapaz/inconsciente, há um esvaziamento político-identitário desse grupo que tende a legitimar as políticas assistencialistas e de higienização. Mudar o enunciado discursivo hegemônico de descartável/incapaz para o de "escolha" é importante para reconhecer a identidade (coletiva e individual) daqueles que optaram por morar na rua. É a base para a politização da luta identitária que deve ter como propósito informar as políticas públicas sobre a necessidade de reconhecer essas vozes anônimas ${ }^{21}$. Acreditamos que esse é um caminho possível para a diminuição do estigma cravado nesses indivíduos. Evidentemente, essa mudança impõe desafios à própria população em situação de rua, pois esse cenário implica novas responsabilidades que não sabemos se os moradores desejarão assumir ${ }^{22}$.

Portanto, um aspecto que nos parece central é compreender a vida nas ruas como uma possibilidade biopolítica. Estimulados pela argumentação de Axel Honneth (2003) ${ }^{23}$, entendemos que a melhoria qualitativa de vida desse grupo passa pelo usufruto de direitos civis e respeito por suas escolhas, contudo esses aspectos não são suficientes como sugerem os textos subsequentes do autor (ver HONNETH 2001; 2008). Honneth $(2003 ; 2008)$ sugere que a luta pelo reconhecimento envolve conquistas nos campos afetivo, político (ligado aos direitos civis, à possibilidade de participação e representação na sociedade) e de estima social. Essa última se justifica pela necessidade humana de desenvolver relações solidárias (partilha de valores e capacidades) no grupo ao qual pertence, objetivando a conquista de prestígio social, mas não prescinde do acesso a recursos materiais para a sobrevivência - dimensão econômica no seu sentido estrito, também chamada de dimensão (re)

21 O reconhecimento não é uma questão de cortesia, é uma necessidade humana (HONNETH, 2003).

22 No caso da atividade de prostituição, outro grupo social "invisível e indesejado", a inclusão da atividade de "profissional do sexo" como uma ocupação formal reconhecida pelo Ministério do Trabalho foi celebrada pelas prostitutas como uma relevante conquista na luta pelo reconhecimento (cf. SIMÕES, 2010). No entanto, a população em situação de rua não conta com essa possibilidade imediata de reconhecimento, pois esse grupo circula por fora do mundo do trabalho formal estabelecido pela economia capitalista.

23 Obra publicada originalmente em 1992. 
distributiva. Honneth $(2001 ; 2008)$ deixa claro que o reconhecimento humano é (também) fruto da contribuição dada ao grupo sob a forma de trabalho social ${ }^{24}$. O autor sugere que o grande desafio é pensar como colocar em prática tal conceito: “[...] como a categoria trabalho social deveria ser incluída no marco de uma teoria social para que dentro dela abra uma perspectiva de melhoria qualitativa que não seja apenas utópica?" (HONNETH, 2008, p. 48).

Pensamos que esse é também o desafio em relação às pessoas em situação de rua. Assim como Honneth (2008), acreditamos na relevância do trabalho como meio de melhoria qualitativa de vida, por reconhecer nessa atividade a possibilidade de autorrealização e subsistência humanas. Ao fim deste artigo, essa constatação se afigura como um caminho necessário de reflexão para pesquisas futuras. Parece-nos que o reconhecimento político da vida nas ruas deve passar obrigatoriamente pela necessidade de se pensar em formas de trabalho capazes de envolver os moradores de rua, criando novas sociabilidades. Essa é uma via possível para fugirmos de um culturalismo banal (ver FRASER, 2002, especialmente o tópico 2). Atuando nessa lacuna, a pesquisa sociológica tem condições de melhor informar os agentes envolvidos no amparo à população em situação de rua e, de fato, interferir na realidade dos moradores. Portanto, seguir nessa direção é nosso estímulo para a continuidade do presente trabalho.

\section{REFERÊNCIAS}

ADORNO, R. C. F.; VARANDA, W. Descartáveis urbanos: discutindo a complexidade da população de rua e o desafio para políticas de saúde. Saúde e Sociedade, São Paulo, v. 13, n. 1, p. 23-45, jan./abr. 2004.

ALBERTSEN, N.; DIKEN, B. Mobility, justification, and the city. Nordic Journal Architectural Research, Copenhagen, v. 14, n. 1, p. 13-24, 2001.

24 Isto é, não um trabalho reduzido a seu papel de dispêndio necessário à produção de mercadorias/serviços pautado na exploração da força de trabalho com vistas à satisfação das necessidades funcionais da sociedade. Mas a busca de um trabalho pautado na cooperação criativa, no desenvolvimento da autoconfiança, autoestima e autorrealização. Para Honneth (2001; 2008), esse conceito sintetiza dois princípios indissociáveis - e mutuamente implicados - na luta pelo reconhecimento: a aceitação de diferentes formas de vida (reconhecimento simbólico/cultural) e a necessidade de subsistência dos grupos/indivíduos e, consequentemente, a inclusão em algum tipo de sistema de produção (reconhecimento material). 
ANGROSINO, M. Etnografia e observação participante. Porto Alegre: Artmed, 2009.

BAKHTIN, M. Marxismo e filosofia da linguagem. 8. ed. São Paulo: Hucitec, 2006.

BOLTANSKI, L.; THÉVENOT, L. De la Justification: les économies de la grandeur. Paris: Gallimard, 1991.

BOTELHO, T. R. Revitalização de centros urbanos no Brasil: uma análise comparativa das experiências de Vitória, Fortaleza e São Luís. Revista EURE, Santiago, v. XXXI, n. 93, p. 53-71, ago. 2005.

CANCLINI, N. G. Cidades e cidadãos imaginados pelos meios de comunicação. Opinião Pública, Campinas, v. 8, n. 1, p. 40-53, maio 2002.

CARRIERI, A. P. A gestão ordinária. 328 f. Tese (Professor Titular) - Faculdade de Ciências Econômicas, Universidade Federal de Minas Gerais, Belo Horizonte, 2012.

CARRIERI, A. P.; MARANHÃO, C. M. S. A.; MURTA, I. B. D. Crítica ao manejo humano em Belo Horizonte. Revista de Administração Pública, Rio de Janeiro, v. 43, n. 6, p. 1315-1342, nov./dez. 2009.

CARRIERI, A. P.; SARAIVA, L. A. S.; LIMA, G. C. O.; MARANHÃO, C. M. S. A. Estratégias subversivas de sobrevivência na "feira hippie" de Belo Horizonte. Gestão Org., Recife, v. 6, n. 2, p. 174-192, maio/ago. 2008.

CERTEAU, M. A invenção do cotidiano: artes de fazer. 3. ed. Petrópolis: Vozes, 1998. V. 1. COSTA, J. L. R. Algumas reflexões sobre cidade saudável. Saúde e sociedade, São Paulo, v. 6, n. 2, p. 65-70, dez. 1997.

DUARTE, F.; CZAJKOWSKI JUNIOR, S. Cidade à venda: reflexões éticas sobre o marketing urbano. Revista de Administração Pública, Rio de Janeiro, v. 41, n. 2, p. 273-282, mar./abr. 2007.

FARIA, A. A. M. Discurso e leitura, semântica e argumentação em Germinal. In: MACHADO, I. L.; CRUZ, A. R.; LYSARDO-DIAS, D. (Org.). Teorias e práticas discursivas: estudos em análise do discurso. Belo Horizonte: UFMG/FALE/NAD/Carol Borges, 1998.

FIORIN, J. L. Semântica e análise do discurso. In: MARI, H.; PIRES, S.; CRUZ, A. R.; MACHADO, I. L. (Org.). Fundamentos e dimensões da análise do discurso. Belo Horizonte: Carol Borges, 1999.

FRASER, N. A justiça social na globalização: redistribuição, reconhecimento e participação. Revista Crítica de Ciências Sociais, Coimbra, v. 63, p. 7-20, 2002.

GEERTZ, C. A interpretação das culturas. Rio de Janeiro: LTC, 2008.

GONZALEZ REY, F. Pesquisa qualitativa e subjetividade: os processos de construção da informação. São Paulo: Pioneira Thomson Learning, 2005.

HONNETH, A. Recognition or redistribution? Changing perspectives on the moral order of society. Theory, Culture \& Society, Abingdon, v. 18, p. 43-55, 2001.

Luta pelo reconhecimento: a gramática moral dos conflitos sociais. Rio de Janeiro: Editora 34, 2003.

Trabalho e reconhecimento: tentativa de uma redefinição. Civitas - Revista de Ciências Sociais, Porto Alegre, v. 8, n. 1, p. 46-67, jan./abr. 2008. 
JAYME, J. G.; NEVES, M. A. Cidade e espaço público: política de revitalização urbana em Belo Horizonte. Caderno CRH, Salvador, v. 23, n. 60, p. 605-617, dez. 2010.

JOSGRILBERG, F. B. Cotidiano e invenção: os espaços de Michel de Certeau. São Paulo: Escrituras, 2005.

. Michel de Certeau e o Admirabile Commercium de sentidos na educação. Educação: Teoria e Prática, Rio Claro, v. 18, n. 30, p. 95-105, jan./jul. 2008.

KUNZ, G. S.; HECKERT, A. L.; CARVALHO, S. V. Modos de vida da população em situação de rua: inventando táticas nas ruas de Vitória/ES. Fractal: Revista de Psicologia, Rio de Janeiro, v. 26, n. 3, p. 919-942, set./dez. 2014.

LEFEBVRE, H. The production of space. London: Routledge, 1998.

LEITE, R. P. Contra-usos da cidade: lugares e espaço público na experiência urbana contemporânea. 2. ed. Campinas: UNICAMP, 2007.

. Localizando o espaço público: gentrification e cultura urbana. Revista Crítica de Ciências Sociais, Coimbra, n. 83, p. 35-54, dez. 2008.

. A inversão do cotidiano: práticas sociais e rupturas na vida urbana contemporânea.

Dados, Rio de Janeiro, v. 53, n. 3, p. 737-756, 2010.

LIMENA, M. M. C. Cidades complexas no século XXI: ciência, técnica e arte. São Paulo em Perspectiva, São Paulo, v. 15, n. 3, p. 37-44, jul. 2001.

MAINGUENEAU, D. Termos-chave da análise do discurso. Belo Horizonte: UFMG, 1998.

MANZINI, E. J. Entrevista semi-estruturada: análise de objetivos e de roteiros. In: SEMINÁRIO INTERNACIONAL DE PESQUISA E ESTUDOS QUALITATIVOS, 2., A pesquisa qualitativa em debate. Anais... Bauru: SIPEQ, 2004. 1 CD.

MARTINS, M. L. R. São Paulo, centro e periferia: a retórica ambiental e os limites da política urbana. Estudos Avançados, São Paulo, v. 25, n. 71, p. 59-72, abr. 2011.

MARX, K. Glosas críticas ao artigo "o rei da Prússia e a reforma social. De um prussiano". Germinal: Marxismo e Educação em Debate, Londrina, v. 3, n. 1, p. 142-155, fev. 2011.

MENDES, M. V. B. Os moradores de rua e suas trajetórias: um estudo sobre os territórios existenciais da população de rua de Belo Horizonte. 133 f. Dissertação (Mestrado em Sociologia) - Faculdade de Filosofia e Ciências Humanas, Universidade Federal de Minas Gerais, Belo Horizonte, 2007.

MENDES, L.; CAVEDON, N. R. A atividade de camelô como prática urbana no contexto das cidades. Urbe, Curitiba, v. 4, n. 1, p 123-140, jan./jun. 2012.

MOSÉ, V. O homem que sabe. Rio de Janeiro: Civilização Brasileira, 2012.

NARDI, H. C.; RIGONI, R. Q. Marginalidade ou cidadania? A rede discursiva que configura o trabalho dos redutores de danos. Psicologia em Estudo, Maringá, v. 10, n. 2, p. 273-282, maio/ago. 2005.

ROESE, A.; GERHARDT, T. E.; SOUZA, A. C.; LOPES, M. J. M. Field diary: construction and utilization in scientific researches. Online Brazilian Journal of Nursing, Niterói, v. 5, n. 3, 2006. 
SÁNCHEZ, F. A reinvenção das cidades na virada de século: agentes, estratégias e escalas de ação política. Revista de Sociologia e Política, Curitiba, v. n. 16, p. 31-49, jun. 2001.

SANTOS, M. Por uma outra globalização: do pensamento único à consciência universal. Rio de Janeiro: Record, 2000.

SANTOS, M. S. Integração e diferença em encontros disciplinares. Revista Brasileira de Ciências Sociais, São Paulo, v. 22, n. 65, p. 51-60, out. 2007.

SARAIVA, L. A. S. Mercantilização da cultura e dinâmica simbólica local: a indústria cultural em Itabira, Minas Gerais. 333 f. Tese (Doutorado em Administração) - Faculdade de Ciências Econômicas, Universidade Federal de Minas Gerais, Belo Horizonte, 2009.

SARAIVA, L. A. S.; CARRIERI, A. P. Organização-cidade: proposta de avanço conceitual a partir da análise de um caso. Revista de Administração Pública, Rio de Janeiro, v. 46, n. 2, p. 547-576, dez. 2012.

SAWAYA, A. L. Políticas públicas: pontos de método e experiências. Estudos Avançados, São Paulo, v. 20, n. 56, p. 131-148, abr. 2006.

SIMÕES, S. S. Identidade e política: a prostituição e o reconhecimento de um métier no Brasil. Revista de Antropologia Social dos Alunos do PPGAS-UFSCar, São Carlos, v. 2, n. 1, p. 24-46, jan./jun. 2010.

SNOW, D.; ANDERSON, L. Desafortunados: um estudo sobre o povo da rua. Petrópolis: Vozes, 1998.

SOUZA, E. L. A.; BECHLER, J. Labirintos na cidade contemporânea. Psicologia: Ciência e Profissão, Brasília, v. 28, n. 2, p. 390-403, jan. 2008.

SOUZA, M. Políticas públicas e espaço urbano desigual: Favela Jardim Maravilha (SP). Estudos Avançados, São Paulo, v. 23, n. 66, p. 267-281, jan. 2009.

VELHO, G. Individualismo, anonimato e violência na metrópole. Horizontes Antropológicos, Porto Alegre, v. 6, n. 13, p. 15-29, jun. 2000.

2006.

. Patrimônio, negociação e conflito. Mana, Rio de Janeiro, v. 12, n. 1, p. 237-248, abr.

VENTURINI, E. A cidade dos outros. Fractal: Revista de Psicologia, Rio de Janeiro, v. 21, n. 2, p. 203-222, maio/ago. 2009.

VOIROL, O. A esfera pública e as lutas por reconhecimento: de Habermas a Honneth. Cadernos de Filosofia Alemã, São Paulo, n. 11, p. 33-56, jan./jun. 2008.

Recebido em: 29-03-2017

Aprovado em: 08-05-2017

Avaliado pelo sistema double blind review.

Editor: Elmo Tambosi Filho

Disponível em http://mjs.metodista.br/index.php/roc 